\title{
The Role of Land Conflict and Land Conflict Resolution in a Peace Process: Mozambique's Return to Agriculture
}

\author{
Jon D. Unruh
}

\begin{abstract}
The massive return and reintegration of refugees and displaced persons in Mozambique (the largest in the history of Africa) has pushed land tenure issues to the fore in the country's peace process. While land re-access for the six million dislocatees is critical for food, security and political stability, conflict over land resources has become a primary concern of the government and both the regional and international community participating in Mozambique's recovery. Based on data recently collected over a year-and-a-half in Mozambique, this paper will look at the problematic issues of land access, land conflict, and land conflict resolution emerging from the recent 16 year war, and highlight the role of organizations from the national to the international, in land conflict resolution.
\end{abstract}

\section{Précis}

Le retour massif et la réintégration des réfugiés et des personnes déplacées au Mozambique (la plus vaste entreprise de réintégration de toute l'histoire de l'Afrique) a mis la question de la propriété terrienne au centre du processus de paix dans ce pays. Alors que l'accès renouvelé à la terre apparaît crucial pour les six millions de personnes relocalisées pour des raisons alimentaires, de sécurité, et de stabilité politique, les conflits en matière de ressources terriennes sont devenus la principale inquiétude du gouvernement et des communautés régionales et internationales impliquées dans la reconstruction du Mozambique. S'appuyant sur des données colligées surle terrain lors d'un séjourd'un an et demi au Mozambique, le présent article étudie la question pro-

Jon D. Unruh, Ph.D., is Instructor in the Office of Arid Lands Studies, Arizona Remote Sensing Center, University of Arizona, Tuscon, USA. blématique de l'accès à la terre, des contentieux fonciers, et de leur résolution, suite à la récente guerre de 16 ans. Sera mis en relief le rôle des organisations nationales et internationales dans la résolution des contentieux fonciers.

\section{Peace Making and Conflict Management}

\section{New Directions Sought}

The 1992 U.S. and then UN intervention in Somalia and the failure of the overall effort to effectively initiate a peace process has become a turning point that has led policy makers and analysts to rethink approaches to peace making and conflict management in general (Oakley 1995; Crocker 1995).

As the forces that contribute to armed conflict within countries merge with geopolitical and geoeconomic realities, and become interpreted in a larger context than the nation or the region, conventional top-down approaches for peace making - tools developed for conflict resolution between countries-are proving ineffective. These tools are inept at addressing the underlying forces that provide a foundation for conflict or a return to conflict (Homer-Dixon 1990; Chopra 1996). At a recent meeting of the UN's Special Political and Decolonization Committee, it was determined that UN Peace Keeping missions needed to address underlying social and economic causes of tension and war as part of peace keeping (Willett 1995). Without such an approach, "peace keeping operations cannot hope to establish the conditions necessary for establishing peace and stability and thus are prone to failure" (Willett 1995).

There is increasing recognition that in developing country agrarian situations, customary and local ways of in- teraction in areas such as access to and use of resources need to be identified within the sociocultural and agroecological contexts of countries prone to and recovering from war, and be incorporated into conventional approaches to peace making (Cohen 1995; Sisk 1995; Unruh 1995). There are indications that if such customary features are identified, recognized, and supported as assets in the larger setting of conflict resolution and peace making on a national and sub-national level, they can become powerful tools in a peace process (Chopra 1996; Horm of Africa Bulletin 1996; Lund 1996).

Following armed conflict, the largescale return of dislocatees and their attempt at reintegration into agricultural pursuits is a problematic aspect of recovery, with great potential for renewed instability via intense competition for what in many cases are limited agronomic resources which can quickly be brought into food production (Unruh 1995). This article considers the role of land tenure dispute resolution within the wider context of a peace process, and then looks at Mozambique's own return to agriculture after 16 years of civil war.

\section{Return and the Role of Critical Resources}

As time begins to convince refugees, internally dislocated populations, and those interested in larger commercial ventures that a peace effort will holdas repeated attempts at cease-fires, peace treaties, and elections frequently do not-these communities then attempt to return to "home areas," proceed elsewhere, or those who are already settled or able to mobilize capital begin to invest in long-term economic strategies. Initial efforts to engage in recovery (from household to national) for largely agrarian societies will drive land and resource tenure 
problems to the fore over large areas in a short time-frame for significant numbers of people.

The post-conflict rehabilitation of many households, land uses and production systems, as well as regional and national food security and economy, will rely on access to the areas where physical security, cultivable land, perennial water, relief assistance, and infrastructure are present together. These critical resource areas will be especially important where they exist within or in proximity to less usable, accessible, secure, or arable zones (Unruh 1995; Scoones 1991; Ibrahim 1993). Intense resource competition in these areas in the early years of recovery will occur in an environment rife with complicated resource tenure disputes, and lacking in functioning tenure dispute resolution mechanisms viewed as legitimate and workable by the parties concerned. This will occur in a context of recent and/or ongoing armed conflict-itself highlighting the issue of legitimacy in government-such that these areas, while crucial to beginning a sustained recovery and a nascent peace process, can also become locations that spark renewed instability (Unruh 1995).

As well, critical resource areas can be key components in the negotiation of a peace settlement, these being among the first, if not the first areas where initial cease-fires are negotiated to occur, and thus are crucial to a peace settlement (Vines 1996).

\section{Land Resource Competition}

Post-conflict perception of rights to land can originate in different situations at different points in time. Exercising such rights will not happen all at once, but over time, as claimants return or migrate to destination areas from different wartime conditions and locations, as well as attempt to take advantage of the confusion, weakened government capacity, and land emptied by dislocation to establish new access rights.

Some of these claims also represent the opportunity for larger-scale commercial agriculture and other land re- source interests to begin to be explored and realized, and these can contribute much to economic recovery. However land resources for this group can be accessed in a very different manner than that utilized by returning dislocatees and already returned smallholders attempting to make short to long-term agricultural decisions. While smallholders gain or regain access to land via local customary tenure structures, commercial and large land interests gain access to land through some remaining portion of the national land tenure system that if at all operable after war, most likely continues in a much crippled form. In one way or another this latter approach to land access usually involves a document of some sort, while land allocated according to customary rules usually does not carry with it such evidence. What emerges then is a situation whereby what is left of the state land tenure system that is used to acquire, control, dispose of, and defend rights to land resources in a post-war period, is profoundly out of step with the realities of reemerging customary social, tenurial, and agroecological constructs. While variants of such a disconnect operate widely in the developing world, and especially in Africa, it is most pronounced, and carries the greatest risk, in critical resource areas of countries recovering from armed conflict, due to the possibility of undoing a tentative peace process. This is made still more problematic by the temporary (lasting years) division of national territory into areas under control of an opponent group(s) involved in the conflict, as part of an ongoing peace process.

\section{Land Conflicts in an "Out of Step" Tenure Context}

Disputes over land resources between participants in a national versus customary tenure system, and the inability of the two to connect in terms of how such disputes are resolved in ways that are viewed as secure and legitimate (and therefore respected) by participants in both systems, can be a very problematic aspect of a peace process. The issue of legitimacy is cru- cial. Civil conflict is based on the perception of non-legitimacy in various forms. For land dispute resolution to work in a context of recent conflict, the question of legitimacy becomes paramount, and must be attended to directly. The importance of such legitimacy in resolving land conflicts (including armed conflict explicitly over land) is noted in studies on Chiapas (Howard and Homer-Dixon 1995), the Gaza Strip (Kelly and Homer-Dixon 1995) and South Africa (Percival and Homer-Dixon 1995) and generally in civil conflicts (HomerDixon 1991).

Disputes over resource access are especially problematic during recovery from a war which dislocates large populations because refugees while in exile often develop political awareness, such that upon their return to home areas, perceived land tenure injustices can be placed in the context of the larger political dynamic (Ek and Karadawi 1991; Basok 1994). Resolution of land conflicts will be particularly important when different production systems (such as small and commercial agriculture) and groups from opposing sides in the war focus agricultural activities onto the same areas. Certain individuals and groups have the means to prevent peace from returning, and will exercise this option if tenure disputes are not resolved in ways that are, at the very least, commonly viewed as having a legitimate, inclusive, transparent, and fair procedure (Africa Watch 1993; Unruh 1995).

\section{Land Dispute Resolution}

The role that land dispute resolution mechanisms play in post-war reconciliation and economic rehabilitation should not be underestimated. That such resolution happens quickly is important to the secure reengagement of populations in familiar land uses, agricultural production and food security, and agricultural contributions to economic recovery and associated trade opportunities. That it happens in ways that are seen as transparent and equitable by most claimants is important because disenfranchisement of 
local populations from land rights is a major factor contributing to instability and resource degradation (Hutchinson 1991).

An important first step in forming legitimate, workable land dispute resolution mechanisms in a post-war context, is state recognition and legitimization of customary tenure regimes. Such state recognition is important for two reasons. First, following war, aspects of customary arrangements-albeit in many cases transformed-will be reestablished and operational before, and perhaps long before, a state recovering from conflict is in a position to formulate, implement, and enforce a national land tenure system backed by a workable land law. Such that when the latter does occur, both derivation and implementation of significant parts of a national tenure system will be more straightforward, and more successful if it incorporates aspects of what is already in place. This holds the possibility at least of creating fewer tenure disputes in the future by building on known tenure arrangements, as opposed to attempting to introduce new tenure rules that can be poorly understood at the local level. The second reason is that many small-scale resource users will have very little confidence in a new and unfamiliar land tenure system established by a state that will almost certainly be viewed as fragile, if not suspect, until such a government proves itself as a legitimate avenue to land tenure security. Failure to recognize and act on such important aspects of a post-war land tenure dynamic will manifest itself in an aggravation of the disconnect between customary and national tenure systems, with disputes between the two systems operating within the context of the still contentious issue of legitimacy and armed conflict. Such a situation then resides much more proximate to physical confrontation than it would otherwise.

An important part of state recognition of customary land tenure systems, is legal (state) recognition of customary evidence pertaining to land claims and land disputes with large land in- terests, even though such customary evidence will rarely include documentation. Legal legitimacy given to customary forms of evidence then encourages large land interests operating within the formal tenure system to "cut a deal" with smallholder communities (e.g., leasing land, roads, schools, wells, etc.), in order to avoid problematic disputes over land that could jeopardize investments and create tenure insecurity for commercial leaseholders.

\section{Characteristics of a Dispute Resolution Procedure}

For a tenure construct involving the customary and formal systems to function in land dispute resolution and peace keeping in situations of recovery from armed conflict, five characteristics take on primary importance:

1) the construct needs to be able to be established quickly;

2) it should embrace and engage the evolving tenure situation and mitigate emerging problems, as opposed to aggravating these or imposing unfamiliar constructs;

3) it should be able to mesh easily with subsequent realities involving development efforts, and priorities and aspirations involving resource access, investment at different levels, export production, and the passage of national legislation;

4) it should be low cost, with this based on a realistic assessment of existing formal and customary institutions; and

5) it should be seen as legitimate.

\section{Mozambique}

\section{Background}

Mozambique has produced more refugees than any other country in Africa (USCR 1994). The most recent conflict (lasting 16 years) together with a six year drought, separated approximately six million people from food producing activities that covered very large areas of productive land. The massive return and reintegration of refugees and displaced persons in Mozambique (the largest in the history of Africa) is a phenomenon that could not be orchestrated (USCR 1993). The UN's International Organization for Migration expects to continue its resettlement activities until the year 2000 (Lauriciano 1995).

As the number of dislocated equalled approximately 50 percent of the national population, the settlement of rural refugees back into agricultural production systems similar to what they once participated in will be critical to future food security, political stability, and to the reformation of the social and land-use foundations upon which relevant development agendas can be built. However Renamo (the insurgency) maintains control over large areas under the peace accord, and these are only beginning to open to outsiders after years of total isolation.

\section{Land Re-Access and the Peace Process in Mozambique}

In a recent study by the UN's Wartorn Societies Project for Mozambique, the land question was highlighted as one of the most significant points of potential instability, and a possible flashpoint for a return to armed conflict (UNRISD 1996). Alden and Simpson (1993) highlight that the land access issue in Mozambique in particular is likely to become a major source of contention with potentially explosive consequences. Galli (1992) states that the land question will be the most important political question in post-war Mozambique, and that if agriculture and peace is to survive, secure land use rights for cultivators must be given priority and a clear land policy and land law that is the guarantor of cultivator rights is needed above all else. It is therefore extremely important that the country possess recognized, legitimate judicial mechanisms regarding land conflict.

Problematic land tenure arrangements have meant that small-scale agriculture in many areas has not had the capacity itself to guarantee the subsistence of the rural family. The problem is further exacerbated by land shortages and land mines. Many demobilized and dislocated have returned to find 
their lands occupied by others, resulting in large numbers of land disputes. This issue is most frequent and problematic in the most fertile (critical resource) areas, where elites from Maputo, wealthy South Africans and Zimbabweans, and a host other larger land interests have claimed land.

Tanner and Monnerat (1995), and Willett (1995), reviewing a number of recent studies on Mozambique, found that there is a direct correlation between the number of land conflicts, and locations where fertile soil, perennial water, infrastructure, and market access, are present together; these being areas of high population density as a result of the war (also World Bank 1994; Hanlon 1995). Especially problematic in these critical resource locations are disputes between smallholders operating within reestablishing customary tenure systems, and larger land interests utilizing the national tenure system to gain access to land. Several researchers state that conflicts between participants in customary and the national tenure system in Mozambique are very serious and will likely intensify (McGregor 1995; MOA/MSU 1994b; Bawa 1996; UNHCR 1996).

\section{Reintegration and Land Access}

\section{For Local Communities}

While many agriculturalists have been able to relocate or return to areas of origin to resume farming and livestock raising, significant numbers continue to move from place to place, depending on land availability. Large areas of agricultural land remain uninhabitable or problematic due to land mines and control by Renamo. Further complicating land access, are large-scale recovery efforts by the international development community to rehabilitate whole agricultural sectors, such as cashew and livestock production. These efforts involve, in these cases, free or greatly subsidized saplings and animals which then need to be connected to the landscape in some wayand are frequently used to claim land.

As recovery progresses and returnees attempt to restart agricultural pro- duction, in any one area there may be several persons or entities claiming land access, especially in the better, or critical resource areas. These include:

1) descendants of the original population which was expelled during the colonial era;

2) people who received parcels from the local administration after independence and during the war;

3) dislocated persons who abandoned their lands and are now returning;

4) people occupying land they found to be abandoned during the war;

5) former land owners from the colonial period;

6) concessions given by state agencies;

7) state collectives dating from the early independence Frelimo (government) era;

8) speculators and others who use the present fluid land tenure situation to acquire resources; and

9) ex-combatants and current officials of both Frelimo and Renamo as part of the peace agreement (officially or unofficially).

\section{For Large Land Interests}

Reintegration of dislocated populations is especially problematic in critical resource areas where aggressive land acquisition of various kinds are underway by large land interests using the state system. In the most agronomically endowed areas, overlapping and conflicting claims and concessions to land are being granted (legally and extra-legally) at different ministries, agencies, and levels of government with no coordination, and usually on land already occupied by smallholder communities (Carrilho 1994). The national tenure system presently operates in an extremely debilitated form, with a very poorly functioning, and poorly coordinated land titling procedure, a lack of a central institution for adjudicating overlapping claims (even within the national tenure system), and virtually no capacity for enforcement; with, again, the added jurisdictional problem of areas still under Renamo control. And international development activities are concen- trated in the most agronomically productive and accessible areas, as these are the locations where results can be quickly and most easily realized (Levy 1996; USAID 1995).

Likewise donor supported recovery of trading, transportation, and marketing of agricultural production, further encourages acquisition of the agronomically valuable and most easily accessible land. And an assumption that pending constitutional reform will have Mozambique switch from a policy of state, to private ownership of land, has led many large land interests to acquire land in the best areas for speculative purposes. At least nine million hectares of land, by conservative estimate, have been awarded by the government in concessions involving farming, hunting, tourism, and mining activities (Moll 1996). Practically all these concessions include settlements of smallholders, who presently are not part of government land allocation decisions and who do not enjoy rights of consultation or veto over allocations (Myers 1994; Moll 1996). These nine million hectares occupy the highest quality land of the 35 million hectares of arable land in the country, including all the major river basins and land near infrastructure and towns (Moll 1996). This has generated large-scale conflict between smallholders and concession holders, with violent confrontation becoming more common (Moll 1996; UNHCR 1996).

\section{Confusion in Land Rights}

Legally all land continues to belong to the state in Mozambique. But with limited capacity to enforce this, there is considerable ambiguity over who actually is the "owner" of landholdings. As a result, there is a great deal of confusion over exactly what rights individuals, communities and the state have. At the same time state ownership has given license to land grabs and land speculation by civil servants and their informal clients-a situation that encourages land disputes, and discredits government legitimacy (Myers 1994). The inability of the Mozambican 
state to insert itself in even a small proportion of land rights transactions involving smallholders has created a situation where most land transactions and activity involving land occur outside the domain of the state in a black market arrangement, where rules of national tenure do not apply. This invites corruption and conflict, further decreasing legitimacy.

\section{The Need for Tenure Dispute Resolution Mechanisms}

Even if the present national tenure framework operated perfectly and the necessary enforcement capacity existed, this would not be able to resolve the complicated land conflicts that are emerging in post-war Mozambique. The central issue is less the lack of a surveying service and an official agency of coordination and arbitrage, than the legitimacy itself of the existing services with the competence to solve land conflict problems given the realities of post-war Mozambique (Tanner and Monnerat 1995). While recent national political change in Mozambique recognizes the legitimacy of local, customary authority structures (MOA 1995a), the existing land law does not recognize customary tenure systems and therefore denies community access rights to land not currently under cultivation. More importantly, the land law does not recognize as legitimate, customary decisions that resolve conflicts between smallholders. Thus, land incorporated in fallow systems, minor forest product extraction, grazing, land otherwise held in "common," or areas belonging to the community but as yet not allocated for cultivation according to customary tenure, emerge as being empty, and are vulnerable to occupation by larger land interests able to get title.

Present land dispute resolution mechanisms employed by the Mozambican state favour those in possession of some form of documentationwhich nearly all returning and reintegrating smallholders do not have. A tribunal or judge must make a decision based only on the evidence presented. While documents pertain- ing to land are admissible forms of evidence in such a proceeding, oral testimony and corroboration are not. Thus, based on admissible forms of evidence, a judge or tribunal presently must make a decision in favour of documentation. Such an inequitable, and from the perspective of small holders, illegitimate arrangement of land tenure dispute resolution, operating in aggregate, carries serious risks toward impoverization, land degradation, rural exodus, and instability. Meanwhile, the General Peace Accord between Renamo and Frelimo states that, "Mozambican refugees and displaced persons shall be guaranteed restitution of property owned by them which is still in existence and the right to take legal action to secure the return of such property from individuals in possession of it" (African-European Institute 1993). The recently revised land policy for Mozambique, which lays the groundwork for subsequent revision of the land law, makes this explicit for small-scale agriculturalists (MOA 1995). However, in addition to there being layers of superimposed claims made at different dates, the dislocation problem together with the recent war and the lack of state authority, creates a situation where the backing to such claims will be extremely variable. Strategies to deal with this complexity must be derived carefully.

\section{Land Policy Reform in Mozambigue}

There is general agreement within the government and donor community in Mozambique that a new land law is an exceedingly important goal, and that there presently exists a window of opportunity to make substantial progress toward significant policy reform. The Minister of Agriculture has made land issues and a new land law a priority.

With support from the donor community, the government of Mozambique is presently seeking to revise the current land law to more effectively address problems, and reflect the tenure situation emerging in the post-war period. Land conflict resolution is one of the primary objectives of this land policy reform. The Inter-Ministerial Land Commission plans to have a revised land law ready to submit to Mozambican Parliament in 1997 as part of a National Land Program. Preliminary versions of the land law contain some very positive elements regarding customary tenure systems, especially when compared to legislation in other SADC countries (Negrao 1996). Within this context, land tenure conflict resolution that is viewed as legitimate by all interests becomes important to the real success of a new land law and land policy reform. A number of donors are waiting to see what kind of land law is passed by Mozambican parliament before deciding what kind (if any) agricultural and recovery projects and programs to fund.

\section{Bibliography}

African-European Institute. 1993. Acordo Geral de Paz de Mocambique. Amsterdam: African-European Institute.

Africa Watch. 1993. "Land Tenure, the Creation of Famine and Prospects for Peace in Somalia." Africa Watch Discussion Paper No. 2.

Alden, C., and M. Simpson. 1993. "Mozambique: A Delicate Peace." Journal of Modern African Studies 31, 109-130.

Basok, T. 1994. "The Troubled Road to Repatriation in Central America: Lessons Learned by Refugees in Exile." Refuge 13, no. 10, 11-12.

Bawa. 1996. "Presentation by the Bawa Community of Mozambique on Tchuma Tchato for the IASCP Conference in Berkeley 'Voices from the Commons."' Unpublished manuscript.

Carrilho, J. 1994. Mozambique: Advisory Policy on Rural Resettlement and Land Tenure. Rome: Food and Agriculture Organization of the United Nations (FAO).

Chopra, J. 1996. "The Space of Peace Building." Political Geography 15, 335-57.

Cohen, H. J. 1995. "African Capabilities for Managing Conflict: The Role of the United States." In African Conflict Resolution: The U.S. Role in Peacemaking, edited by D. R. Smock and C. A. Crocker. Washington, DC: United States Institute of Peace.

Crocker, C. A. 1995. "What Kind of Role in African Conflict Resolution?" In African Conflict Resolution: The U.S. Role in Peacemaking, edited by D. R. Smock and C. A. Crocker. Washington, DC: United States Institute of Peace. 
Ek, R., and A. Karadawi. 1991. "Implications of Refugee Flows on Political Stability in the Sudan." Ambio 20, 196-203.

Galli, R. 1992. "Who Will Rehabilitate Agriculture in the Post-War Period?" Unpublished manuscript.

Hanlon, J. 1995. "Dual Administration Continues." Mozambique Peace Process Buletin, December.

Homer-Dixon, T. F. 1990. "Environmental Change and Violent Conflict." Occasional Paper No. 4, International Securities Studies Program, American Academy of Arts and Sciences, Cambridge, MA, USA.

- 1991. "On the Threshold: Environmental Changes as Causes of Acute Conflict." International Security 16, 85.

Horn of Africa Bulletin (HAB). 1996. "Early Warning and Conflict Prevention." Vol. 8 , no. 1, 1, 35 .

Howard, P., and T. F. Homer-Dixon. 1995. "Environmental Scarcity and Violent Conflict: The Case of Chiapas, Mexico." Project on Environment, Population, and Security, University of Toronto, Toronto.

Hutchinson, R. A. 1991. "Fighting for Survival: Insecurity, People and the Environment on the Horn of Africa." Based on a study by B. S. Spooner, and N. Walsh, IUCN Gland, Switzerland.

Ibrahim, F. 1993. "A Reassessment of the Human Dimension of Decertification." Geojournal 31, 5-10.

Kelly, K., and T. F. Homer-Dixon. 1995. "Environmental Scarcity and Violent Conflict: The Case of Gaza." Project on Environment, Population, and Security, University of Toronto, Toronto.

Lauriciano, G. 1995. "Zimbabwean Dissidents in Mozambique." Inview 16, 12.

Levy, C. 1996. Personal Communication, Food Security Project, Dutch Embassy, Maputo.

Lund, M. 1996. "Preventive Diplomacy: A Strategy for Preventing Violent Conflicts." Washington, DC: U.S. Institute of Peace.

McGregor, J. 1995. "Staking Their Claims: Land Disputes in Southern Mozambique." Unpublished manuscript.

Ministerio de Agricultura/Michigan State University (MOA/MSU). 1994. "Evolution of the Rural Economy in Post-War Mozambique: Insights from a Rapid Rural Appraisal in Monapo District of Nampula Province." MOA/MSU Working Paper No. 16, Maputo.

Ministerio de Agricultura (MOA). 1995. Politica Nacional de Terras e Estrategia de Implementacao. Maputo: Comissao de Terras, Ministerio de Agricultura.
Moll, P. 1996. "Call for Prompt Action on the Mozambique Draft Bill on Land." World Bank Mozambique land brief position paper. Maputo: World Bank.

Myers, G. 1994. “Competitive Rights, Competitive Claims: Land Access in Mozambique." Journal of Southern African Studies 20, 603-33.

Negrao, J.1996. Alternativas para o sector familiar. Nucleo de Estudos da Terra (NET), Universidade Eduardo Mondelane.

Oakley, R. B. 1995. “A Diplomatic Perspective on African Conflict Resolution." In African Conflict Resolution: The U.S. Role in Peacemaking, edited by D. R. Smock and C. A. Crocker. Washington, DC: United States Institute of Peace.

Percival, V., and T. Homer-Dixon. 1995. "Environmental Scarcity and Violent Conflict: The Case of South Africa." Project on Environment, Population, and Security. University of Toronto, Toronto.

Scoones. I. 1991. “Wetlands in Drylands: Key Resources for Agricultural and Pastoral Production in Africa." Ambio 20, 366-71.

Sisk, T. D. 1995. "Institutional Capacity Building for African Conflict Management." In African Conflict Resolution: The U.S. Role in Peacemaking, edited by D. R. Smock, and C. A. Crocker. Washington, DC: United States Institute of Peace.

Tanner, C. R., and J. B. Monnerat. 1995. “Bases for a National Land Program, Including the Revision of the Land Law, and the Links with Other Pertinent Programs and Projects." Project Support to the Land Commission (TCP/MOZ/2335). Minis- try of Agriculture and Fishing, Republic of Mozambique, Food and Agriculture Organization of the United Nations.

UN Research Institute for Social Development (UNRISD). 1996. Mozambique Case Study. Maputo: Programme for Strategic and International Security Studies, UNRISD.

Unruh, J. D. 1995. "Post-Conflict Recovery of African Agriculture: The Role of 'Critical Resource' Tenure." Ambio 24, 343-48.

U. S. Agency for International Development (USAID). 1995. Mozambique Country Strategic Plan FY 1996-FY 2001. Maputo: USAID.

- 1996. USAID/Mozambique Results Review, FY 1995. Maputo: USAID Mozambique Mission.

U.S. Committee for Refugees (USCR). 1993. World Refugee Survey. Washington, DC: U.S. Committee for Refugees.

—. 1994. World Refugee Survey. Washing ton, DC: U.S. Committee for Refugees.

Vines, A. 1996. "Renamo: From Terrorism to Democracy in Mozambique?" Center for Southern African Studies, University of York, York, UK.

Willet, S. 1995. "Ostriches, Wise Old Elephants and Economic Reconstruction in Mozambique." International Peacekeeping 2, 34-55.

World Bank. 1994. "Country Environmental Strategy Paper for the Republic of Mozambique." World Bank, Southern Africa Department, Report No. 13251 MOZ. a

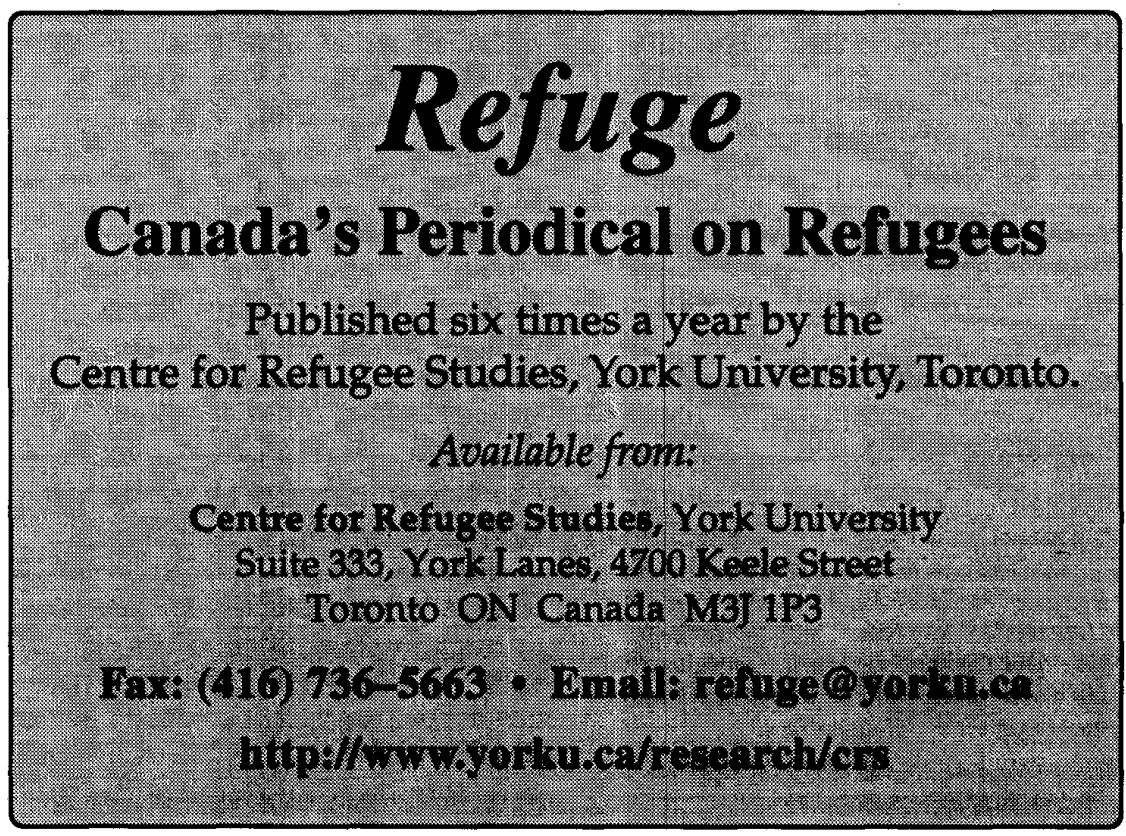

Refuge, Vol. 16, No. 6 (December 1997) 